\title{
Control of Peach Scab with Reduced Midseason Fungicide Programs
}

\author{
H. Scherm and A. T. Savelle, Department of Plant Pathology, University of Georgia, Athens 30602
}

\begin{abstract}
Scherm, H., and Savelle, A.T. 2001. Control of peach scab with reduced midseason fungicide programs. Plant Dis. 85:706-712.

The effectiveness of reduced fungicide programs, using either extended application intervals or alternate-row middle (ARM) spraying of wettable sulfur or captan, on infection of peach fruit by Cladosporium carpophilum was investigated in a 2-year study in Georgia. Fungicide reductions focused on the midseason cover spray period when scab pressure is typically reduced and when growers would be most likely to adopt reduced spray programs because of the potential for fewer insecticide applications at the same time. In an experimental orchard, sulfur was applied at calyx split and calyx fall, followed by another application of sulfur or captan at first cover. Subsequent midseason applications consisted of sulfur at 12- to 14-day intervals (standard); sulfur at extended 24- to 28-day intervals; or either sulfur or captan applied via ARM spraying at 12- to 14-day intervals at reduced sprayer speed. Plots without midseason sprays after first cover also were included. Fruit scab severity was reduced by all fungicide programs compared with the untreated control. Disease severity with sulfur applied at extended intervals and with ARM spraying of sulfur or captan was not significantly different from that of the standard $(P>0.05)$ in both years, suggesting that application intensity during midseason can be reduced without compromising scab control. By contrast, plots that did not receive any midseason sprays after first cover had significantly more disease. Reduced midseason applications of sulfur were further evaluated in two commercial orchards. In one orchard, fruit scab control achieved with extended-interval or ARM spraying during midseason was not significantly different from that of the grower standard. In the second orchard, higher disease severity resulted from midseason ARM applications compared with the standard, presumably because of the longer (14- to 18-day) spray interval used by the cooperating grower for ARM spraying. Reduced midseason fungicide programs did not lead to an increased carryover of inoculum as determined by conidial counts on overwintered twigs at petal fall in the following year.
\end{abstract}

Additional keywords: Prunus persica, sulfur residue

Scab, caused by the hyphomycete Cladosporium carpophilum, has been recognized in peach (Prunus persica) production areas worldwide since the early 1900s (13). The disease is most severe in temperate regions typified by a long growing season with high humidity and abundant rainfall in spring and early summer $(8,16)$. Most direct losses can be attributed to the formation of dark, raised lesions that diminish the appearance of affected fruit. In addition, severely diseased fruit may be misshapen and may exhibit cracking, thereby increasing susceptibility to other pre- or postharvest pathogens. As crop value is ultimately determined through a system of quality grades (1), any factor which decreases that quality impacts marketability and economic returns. Economic losses can be substantial in the southeastern United States where conditions are generally

Corresponding author: H. Scherm

E-mail: scherm@uga.edu

Accepted for publication 9 March 2001.

Publication no. D-2001-0430-01R

(C) 2001 The American Phytopathological Society favorable for scab development. In Georgia in 1999, the disease reduced total crop value by an estimated $\$ 3.4$ million through direct damage to fruit and in cost of control measures (23).

Although of little economic concern, infections caused by $C$. carpophilum on current-season twigs are of great epidemiological importance. Indeed, primary infection of expanding twigs and developing fruit in the spring results solely from conidia produced on 1-year-old twigs. In the southeastern United States, conidia of $C$. carpophilum are first evident on overwintered twig lesions in early spring around bloom, with peak production occurring within 2 months of petal fall $(5,13,14)$. Diminishing conidial numbers thereafter and the prolonged incubation period of $C$. carpophilum (42 to 77 days on fruit in the orchard) (13) render late fruit infections relatively unimportant except on latematuring cultivars. Based on these considerations, fungicide applications against scab are most critical during early fruit development (from petal fall or calyx split until about 2 months after petal fall). Still, subsequent applications may be beneficial in reducing twig infections $(13,14)$, thereby decreasing the amount of inoculum carried into the following year.
Based on detailed studies of the biology of $C$. carpophilum in concert with extensive disease management trials, Keitt (13) determined that fruit infection could be controlled effectively with sulfur applied 4 weeks after petal fall, followed by one or two additional sprays at 3 to 4-week intervals after the initial treatment. His recommendations were followed until the early 1950s when a season-long fungicide schedule was adopted. Several factors may have contributed to this shift, including more stringent fruit quality standards and a marked increase in scab reported by producers in several previous years (17). In addition, the need for more intensive, season-long insect control, along with the low cost of some fungicides, led to the recommendation to tank-mix and apply insecticides and fungicides simultaneously, resulting indirectly in a more intensive fungicide program. Finally, the development and commercialization of the airblast sprayer during that period (21) may have played an important role; indeed, a calendarbased schedule with close application intervals would have been impossible without the relative ease and speed associated with airblast spraying. As a result, current recommendations for scab control in the southeastern United States comprise a series of sprays beginning at petal fall or calyx split and continuing at 1 to 2-week intervals until 3 to 4 weeks before harvest (11). While several fungicides are labeled against scab, sulfur and captan are the most commonly used active ingredients in the southeastern states. Sulfur is often preferred by producers in Georgia because of its low cost.

More recently, interest has broadened from the singular focus of improving fruit quality to include economic and environmental concerns associated with pesticide use. Responses have been diverse, ranging from research to adapt or refine existing technologies to resistance breeding and developing biological and environmental models for predicting pest outbreaks. Although strategies for reducing pesticide use based on resistant cultivars or pest prediction are potentially very useful, they must be developed and evaluated over an extended period. By contrast, changes in existing technology, such as altering application timing or method, are more quickly evaluated and implemented. Examples of the latter include extended spray intervals or alternate-row middle (ARM) spraying during periods of reduced pest pressure. ARM spraying exploits the multiple-row coverage (drift) associated with airblast spraying by applying pesticide in every other row middle, whereby the sides of tree rows receiving 
Table 1. Fungicide programs for control of scab, caused by Cladosporium carpophilum, in an experimental peach orchard cv. Blake in 1997 and 1998

\begin{tabular}{llll}
\hline & & \multicolumn{2}{c}{ Application timing } \\
\cline { 2 - 3 } Trtmt. no. & Calyx split and calyx fall & First cover $^{\mathbf{a}}$ & Midseason sprays \\
\hline 1 & $\ldots$ & $\ldots$ & $\ldots$ \\
2 & Sulfur & Sulfur & Sulfur at 12- to 14-day intervals \\
3 & Sulfur & Sulfur & Sulfur at 24- to 28-day intervals \\
4 & Sulfur & Sulfur & Sulfur ARMc at 12- to 14-day intervals \\
5 & Sulfur & Sulfur & $\ldots$ \\
6 & Sulfur & Captan & \\
7 & Sulfur & Captan & Captan ARM at 12- to 14-day intervals \\
\hline
\end{tabular}

${ }^{a}$ In 1997, the spray was reapplied due to heavy rain after the initial application.

b Wettable sulfur was applied at $10.1 \mathrm{~kg}^{\mathrm{a}}$.i. ha $\mathrm{h}^{-1}$ during conventional and alternate-row middle applications; the rate was increased to $15.1 \mathrm{~kg}$ a.i. $\mathrm{ha}^{-1}$ in treatments 3 to 5 at first cover and in treatment 3 during the mid-season sprays.

${ }^{c} \mathrm{ARM}=$ alternate-row middle application at reduced sprayer speed

${ }^{\mathrm{d}}$ Captan was applied at $2.80 \mathrm{~kg}$ a.i. ha ${ }^{-1}$ at first cover and at $1.87 \mathrm{~kg}$ a.i. $\mathrm{ha}^{-1}$ during alternate-row middle applications. direct spray alternate at each application time. Lewis and Hickey (15) advocated the ARM spray technique, in conjunction with shorter application intervals to ensure the continued presence of sufficient pesticide residue for effective control, as an alternative to conventional spraying in every row middle. In conditions of reduced pest pressure, however, ARM spraying could be implemented using conventional application intervals, thereby reducing pesticide input and/or the time needed for application. This has been proposed recently for midseason insect control in southeastern peaches (12). Because fungicides are generally tank-mixed and applied simultaneously with insecticides, an ARM-based insecticide strategy, if implemented, would indirectly impact disease control.

The objective of this study was to compare the effectiveness of reduced midseason fungicide programs, using either extended application intervals or ARM

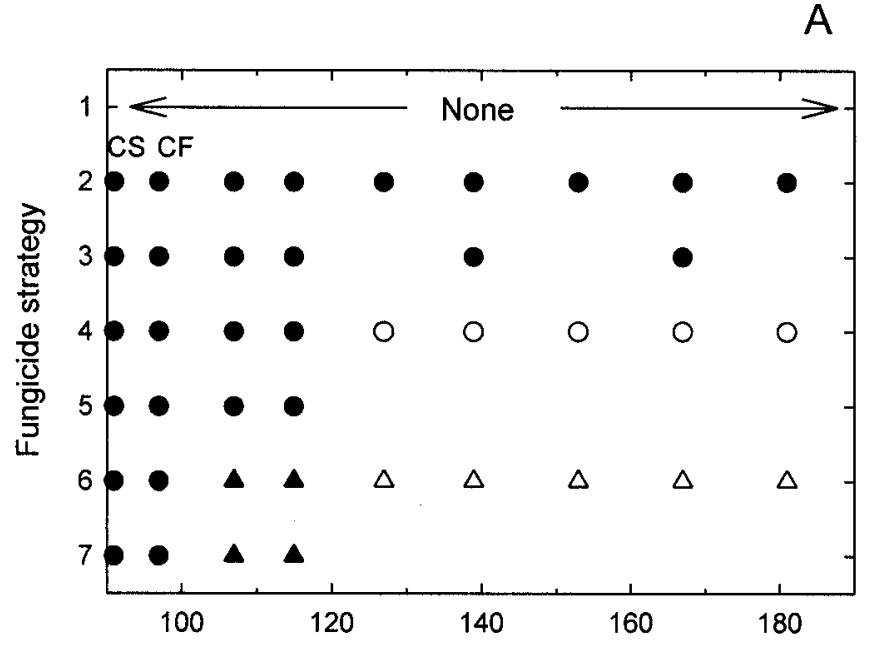

B

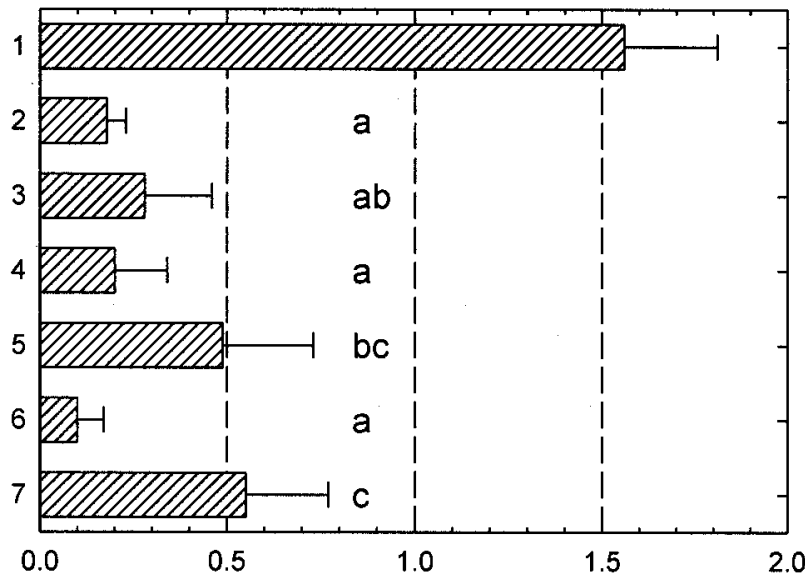

Fruit scab severity (\%)

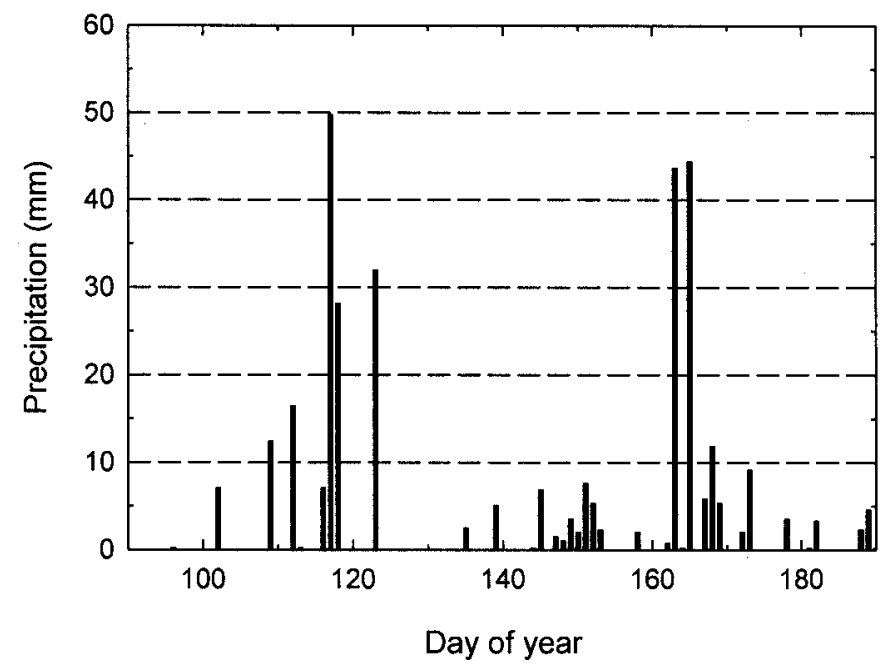

Fig. 1. Experimental peach orchard cv. Blake, 1997: A, fungicide application timing; B, precipitation, and C, fruit scab severity at harvest in a study of reduced fungicide programs against Cladosporium carpophilum. Solid and open symbols in A indicate conventional and alternate-row middle sprays, respectively; circles and triangles indicate applications of wettable sulfur and captan, respectively. Values in $\mathbf{C}$ are means and standard errors of four replicate plots with 120 fruit assessed per plot; means with the same letter are not significantly different according to a multiple $t$ test at $\alpha=$ 0.05 , whereby data from untreated control plots were excluded from the analysis. CS = calyx split, CF = calyx fall. See Table 1 for fungicide schedules and rates. 
spraying of sulfur or captan, on fruit infection by $C$. carpophilum in experimental and commercial orchards. The midseason spray period (after first or second cover), when scab pressure is typically reduced $(5,13,14)$, would be the most likely period for growers to adopt reduced fungicide programs because of the potential for fewer insecticide applications at the same time. Brief reports with preliminary data have been published $(18,19)$.

\section{MATERIALS AND METHODS}

Experimental orchard. Field tests were carried out in 1997 and 1998 at the University of Georgia Horticulture Farm in Oconee County in northeastern Georgia. An experimental orchard of mature peach trees cv. Blake averaging ca. $2.2 \mathrm{~m}$ in height and planted at a spacing of $3.0 \mathrm{~m}$ (in-row) by $6.1 \mathrm{~m}$ was used. Each test was designed as a randomized complete block with seven treatments (Table 1) and four replications. No fungicides were applied before calyx split. Except for the untreated control (treatment 1), which received no fungicide, all plots received two sprays of sulfur (Yellow Jacket Wettable Dusting Sulfur, $90 \%$ a.i.; Georgia Gulf Corp., Atlanta, GA) at calyx split and calyx fall, followed by another spray of either sulfur (treatments 2-5) or captan (Captan 50WP, $48.9 \%$ a.i.; Micro Flo Co., Lakeland, FL) (treatments 6 and 7) at first cover. In the standard (treatment 2), five (1997) or four (1998) additional sprays were made with sulfur at 12 - to 14-day intervals. In treatments 3 and 4, application intensity after first cover was reduced by applying sulfur at 24- to 28-day intervals using the conventional spray technique (i.e., spraying in every row middle) or at 12- to 14-day intervals using the ARM spray technique while concomitantly reducing sprayer speed by $25 \%$. Treatment 6 was similar to treatment 4 except that captan was used instead of sulfur at first cover and in the ARM sprays. Treatments 5 and 7 received no fungicide after first cover. Application schedules and times are summarized in Table 1 and Figures 1A and 2A.

Individual plots were four trees long (including one buffer tree at each end) and one row (conventional sprays) or five rows (ARM sprays) wide and were separated by untreated buffer rows. Fungicides were applied with an airblast sprayer (Model DA500CUD; Durand-Wayland Inc., LaGrange, GA) at a pressure of $1,035 \mathrm{kPa}$ and a speed of 2.5 (conventional) or 1.9 (ARM) $\mathrm{km} \mathrm{h}^{-1}$ in a water volume of 560 or 370 liters $\mathrm{ha}^{-1}$, respectively. The amount of sulfur applied per hectare and spray was identical for the standard and ARM plots; this was accomplished by decreasing sprayer speed $(\times 0.75)$ and increasing sulfur concentration $(\times 1.5)$ in the spray to compensate for spraying only every other tree row. Sulfur concentration also was in-

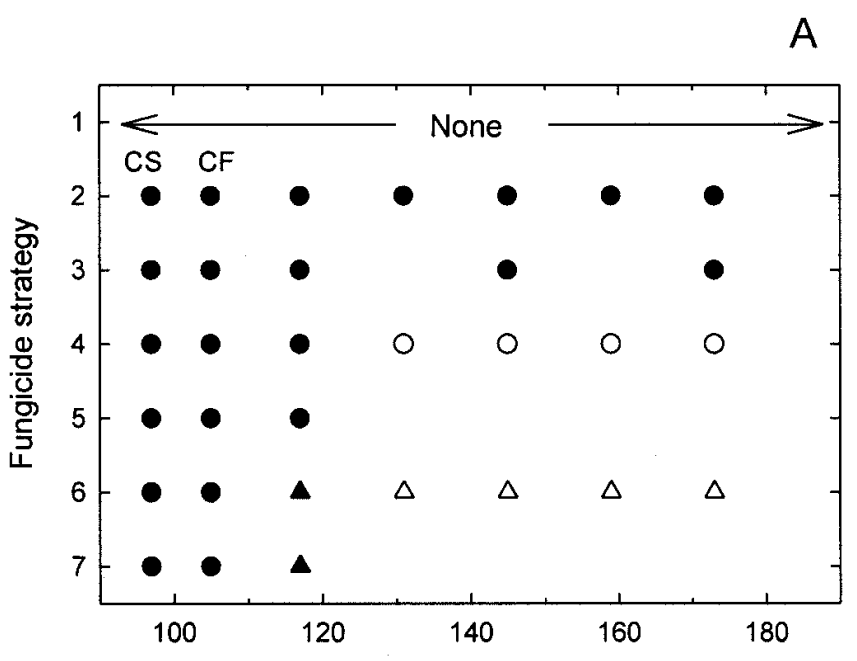

B

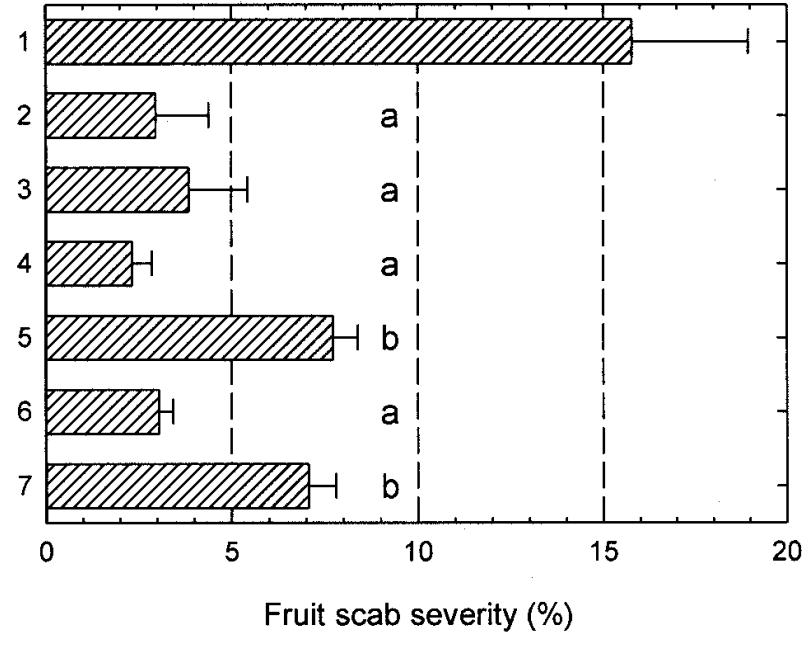

Fruit scab severity (\%)

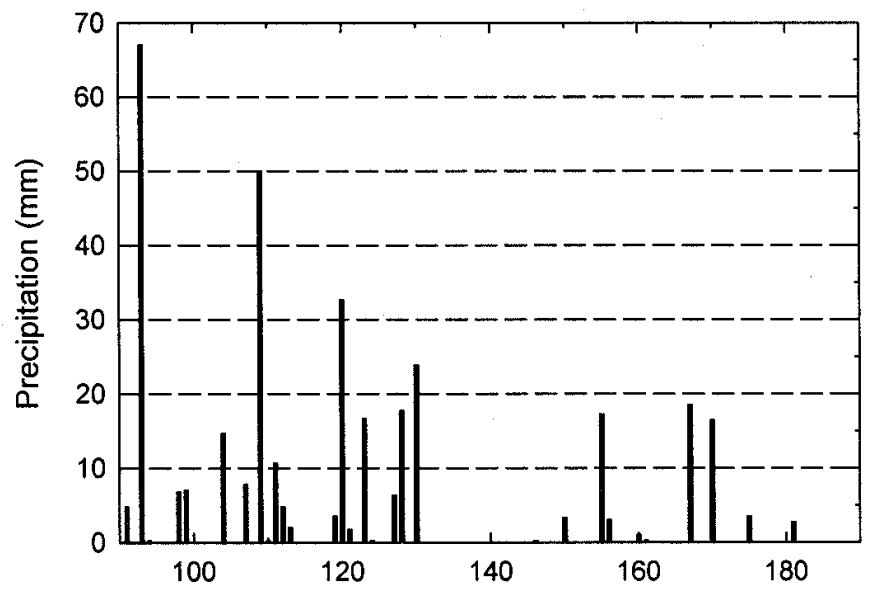

Day of year

Fig. 2. Experimental peach orchard cv. Blake, 1998: A, fungicide application timing; B, precipitation, and $\mathbf{C}$, fruit scab severity at harvest, in a study of reduced fungicide programs against Cladosporium carpophilum. Solid and open symbols in A indicate conventional and alternate-row middle sprays, respectively; circles and triangles indicate applications of wettable sulfur and captan, respectively. Values in $\mathbf{C}$ are means and standard errors of four replicate plots with 120 fruit assessed per plot; means with the same letter are not significantly different according to a multiple $t$ test at $\alpha=0.05$, whereby data from untreated control plots were excluded from the analysis. $\mathrm{CS}=$ calyx split, $\mathrm{CF}=$ calyx fall. See Table 1 for fungicide schedules and rates. 
creased $(\times 1.5)$ with the extended-interval sprays, but sprayer speed was not changed. Application rates are summarized in Table 1.

Commercial orchards. In 1998, two additional tests were carried out in collaboration with commercial growers in Crawford County in central Georgia on mature peach trees cv. Sunprince (site A) and Flameprince (site B), both planted at a spacing of $5.5 \mathrm{~m}$ (in-row) by $6.1 \mathrm{~m}$. Treatment strategies were similar to treatments 1 to 4 above with the following modifications (Tables 2 and 3): (i) both growers initiated their scab spray program at petal fall; (ii) extended-interval and ARM spraying commenced after second cover; and (iii) fungicide concentrations were not increased for extended-interval and ARM spraying, resulting in a lower amount of active ingredient applied per ha and spray for ARM plots compared with standard plots.

Spray timing for the standard, from which all other treatment strategies were derived, was determined independently by each grower. Grower A (Fig. 3A) made more frequent applications than grower $\mathrm{B}$ (Fig. 4A).

Each test was designed as a randomized complete block with three replications. At site A, individual plots were three rows (conventional sprays) or five rows (ARM sprays) wide and $>200 \mathrm{~m}$ long. At site $\mathrm{B}$, plot dimensions were four rows (conventional sprays) or six rows (ARM sprays) wide and four trees long (including one buffer tree at each end). Untreated controls were included at both sites, but these plots contained fewer trees and were arranged independently of the randomization of the remaining treatments. Applications were made by each grower with commercial airblast sprayers at a speed of 1.9 (conventional sprays) or 1.2 (ARM sprays) $\mathrm{km} \mathrm{h}^{-1}$ in a water volume of 560 or 420 liters ha ${ }^{-1}$, respectively.

Sulfur residues. Three to five hours after the second cover spray in the experimental orchard on 7 May 1997 and 11 May 1998, fruit were sampled from control (treatment 1), standard (treatment 2), and ARM plots (treatment 4). Ten fruit from the interior and exterior portions of the canopy were collected separately from the north and south sides of one or two trees per plot. Sulfur was recovered by washing each group of ten fruit in $250 \mathrm{ml}$ Milli-Q water containing $0.05 \%$ Tween 80 on a wrist-action shaker for $20 \mathrm{~min}$. The wash water was vacuum-filtered and the suspended sulfur collected on a $0.45-\mu \mathrm{m}$ nylon membrane (Gelman Sciences Inc., Ann Arbor, MI). After resuspending the residue in $95 \%$ acetone in 20-ml glass vials in an ultrasonic bath for $30 \mathrm{~min}$, sulfur concentration was determined with a colorimetric assay $(2,20)$. Diameter of each fruit was measured and corresponding surface area estimated using the equation for the sur- face of a sphere. Residual sulfur was expressed as micrograms per square millimeter of fruit surface area, and means and standard errors were calculated separately for the north and south sides of the trees based on four replicate plots per treatment.

Disease assessment. At all sites and in both years, fruit scab incidence and severity were assessed at the firm-ripe stage of fruit development on a sample of 120 fruit per plot before preharvest fungicide applications against brown rot (caused by Monilinia fructicola) had been initiated. Fruit scab severity was estimated visually as the percentage of affected surface area on individual fruit. Means and standard errors were calculated based on four (experimental orchard) or three (commercial orchard) replicate plots per treatment.

Overwintered inoculum. At petal fall in early April of 1999, conidial inoculum density on twig lesions formed during the tests in the previous summer was determined in the two commercial orchards. At the time of sampling, no fungicide had been applied at site A, while site B had received one application of sulfur at 10.1 $\mathrm{kg}$ a.i. ha ${ }^{-1}$. Ten 20-cm-long segments were excised from the proximal portion of 1year-old twigs from each plot at each site, transported to the laboratory, misted with distilled water, and incubated in moist chambers for $24 \mathrm{~h}$ to induce sporulation by C. carpophilum. Twig samples were processed as described previously (5) by cutting them into 3- to 5-cm segments, washing them in sterile water containing $0.05 \%$ Tween 80 on a wrist-action shaker for 20 min, and filtering the wash water through two layers of cheesecloth. After concentrating the wash water by centrifugation at
$3,170 \times g$ for $10 \mathrm{~min}$, conidial concentrations were determined with the aid of a hemacytometer and expressed as the number of conidia per $\mathrm{cm}$ of twig. Conidia of C. carpophilum were distinguished from those of saprophytic Cladosporium species based on their shape, size, and pigmentation (13).

Statistical analysis. Arcsine-square root-transformed disease severity data from each test were subjected to analysis of variance for a randomized complete block design (SAS version 6.12; SAS Institute Inc., Cary, NC), followed by means separation using multiple $t$-tests at $\alpha$ $=0.05$. Data from untreated control plots were excluded from these analyses to increase the sensitivity in detecting differences between the reduced fungicide programs and the standard; this was done to decrease the probability of falsely declaring no difference between reduced programs and the standard. Untransformed data on conidial production on overwintered twig samples were analyzed similarly.

\section{RESULTS}

Experimental orchard. Cool, rainy weather favorable for infection by C. carpophilum prevailed during the spring of 1997 and 1998 (Figs. 1B and 2B), resulting in fruit scab incidence $>80 \%$ in untreated control plots (data not shown). Scab severity also was highest in these plots (Figs. 1C and 2C), with disease being more severe in 1998 than in 1997. Increased scab severity in 1998 could have been due to higher early-season rainfall (Fig. 2B) and/or inoculum buildup in the orchard because many trees remained unsprayed in both years.

Table 2. Fungicide programs for control of scab, caused by Cladosporium carpophilum, in a commercial peach orchard cv. Sunprince in 1998 (site A)

\begin{tabular}{cllll}
\hline & & \multicolumn{2}{c}{ Application timing } \\
\cline { 3 - 5 } Trtmt. no. & Petal fall & $\begin{array}{l}\text { Calyx split } \\
\text { and calyx fall }\end{array}$ & $\begin{array}{l}\text { First and } \\
\text { second cover }\end{array}$ & Midseason sprays \\
\hline 1 & $\ldots$ & $\ldots$ & $\ldots$ & $\ldots$ \\
2 & Sulfur & Sulfur & Sulfur & Sulfur at 6- to 16-day intervals \\
3 & Sulfur & Sulfur & Sulfur & Sulfur at 13- to 29-day intervals \\
4 & Sulfur & Sulfur & Sulfur & Sulfur ARM ${ }^{\mathrm{b}}$ at 6- to 16-day intervals \\
\hline
\end{tabular}

${ }^{\text {a }}$ Wettable sulfur was applied at 10.1 and $7.6 \mathrm{~kg}$ a.i. ha ${ }^{-1}$ during conventional and alternate-row middle applications, respectively.

${ }^{\mathrm{b}} \mathrm{ARM}=$ alternate-row middle application at reduced sprayer speed.

Table 3. Fungicide programs for control of scab, caused by Cladosporium carpophilum, in a commercial peach orchard cv. Flameprince in 1998 (site B)

\begin{tabular}{|c|c|c|c|c|}
\hline \multirow[b]{2}{*}{ Trtmt. n } & \multicolumn{4}{|c|}{ Application timing } \\
\hline & o. Petal fall & $\begin{array}{l}\text { Calyx split } \\
\text { and calyx fall }\end{array}$ & $\begin{array}{l}\text { First and } \\
\text { second cover }\end{array}$ & Midseason sprays \\
\hline 1 & $\cdots$ & & $\ldots$ & \\
\hline 2 & Sulfur $^{\mathrm{a}}$ & Sulfur & Sulfur & Sulfur at 14 - to 18 -day interval \\
\hline 3 & Sulfur & Sulfur & Sulfur & Sulfur at 32-day interval \\
\hline 4 & Sulfur & Sulfur & Sulfur & Sulfur $\mathrm{ARM}^{\mathrm{b}}$ at 14 - to 18 -day interval \\
\hline
\end{tabular}

a Wettable sulfur was applied at 10.1 and $7.6 \mathrm{~kg}$ a.i. ha ${ }^{-1}$ during conventional and alternate-row middle applications, respectively.

b $\mathrm{ARM}=$ alternate-row middle application at reduced sprayer speed. 
All fungicide programs reduced disease severity considerably compared with the untreated control in both years (Figs. 1C and $2 \mathrm{C}$ ). The level of control achieved with sulfur applied at extended intervals (treatment 3) and with sulfur or captan applied via ARM spraying (treatments 4 and 6) was not significantly different from that of the sulfur standard (treatment 2). By contrast, the plots that did not receive any fungicide after first cover (treatments 5 and 7) had significantly higher levels of fruit infection (Figs. 1C and 2C).

Commercial orchards. Fruit scab severity was lower at site $A$ than at site $B$ (Figs. 3B and 4B), presumably because of the longer spray interval used by grower $B$ (Figs. 3A and 4A). At site A, the level of scab control achieved with the extended- interval program (treatment 3) and with ARM spraying (treatment 4) was not significantly different from that of the grower standard (treatment 2). At site B, however, ARM spraying resulted in significantly more severe fruit infection compared with the grower standard, presumably because of the longer (14- to 18-day) spray interval used by this grower (Table 3). The extended-interval program was intermediate at this site (Fig. 4B).

Sulfur residues. In plots that received sulfur via conventional spraying, sulfur residues on fruit collected on the south and north sides of the trees were similar (Fig. 5). In ARM plots, sulfur residues were higher on fruit collected from the side of the tree to which the spray was directed; however, residues on the side receiving only indirect spray were within a range ( 1.0 to $2.1 \mu \mathrm{g} \mathrm{mm}^{-2}$ ) similar to that measured in standard plots (1.0 to $1.6 \mu \mathrm{g} \mathrm{mm}^{-2}$ ). Very low quantities of sulfur were recovered from fruit collected in untreated control plots in both years (Fig. 5).

Overwintered inoculum. Assessment of inoculum density in the commercial orchards in the spring following the fungicide tests showed that conidial numbers were greatest in plots that had not received fungicide in the previous year (Figs. 3C and $4 \mathrm{C}$ ). Conidial production potential was reduced in all other plots at both sites, without significant differences between the extended-interval program (treatment 3), the ARM spray technique (treatment 4), and the grower standard (treatment 2). Overall, conidial numbers were substan-
A
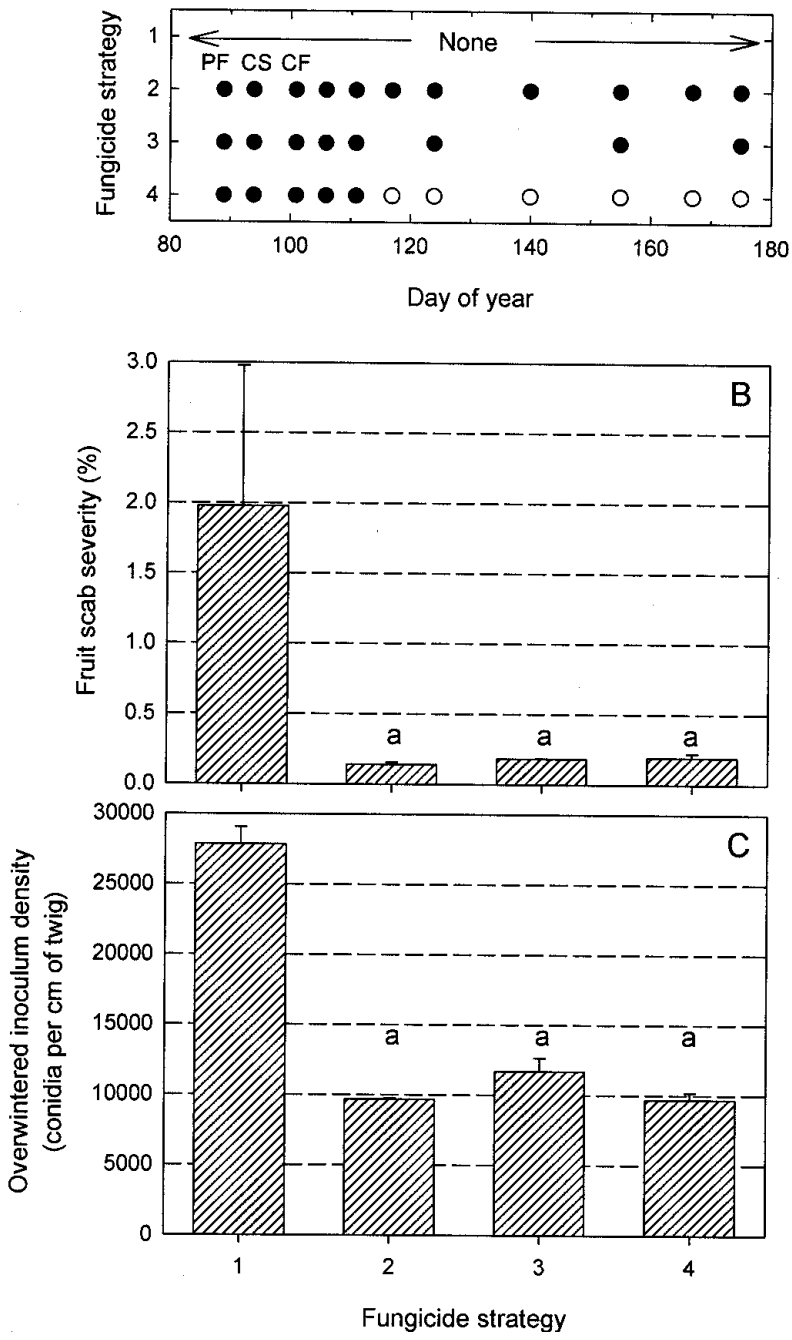

Fig. 3. Commercial peach orchard cv. Sunprince, 1998, site A. A, Fungicide application timing; $\mathbf{B}$, fruit scab severity at harvest, and $\mathbf{C}$, density of overwintered inoculum on twigs early in the following year in a study of reduced fungicide programs against Cladosporium carpophilum. Solid and open symbols in $\mathbf{A}$ indicate conventional and alternate-row middle sprays, respectively. Values in $\mathbf{B}$ and $\mathbf{C}$ are means and standard errors of three replicate plots with 120 fruit or 10 twigs assessed per plot; means with the same letter are not significantly different according to a multiple $t$ test at $\alpha=0.05$, whereby data from untreated control plots were excluded from the analysis. $\mathrm{PF}=$ petal fall, $\mathrm{CS}=$ calyx split, $\mathrm{CF}=$ calyx fall. See Table 2 for fungicide schedules and rates.
A
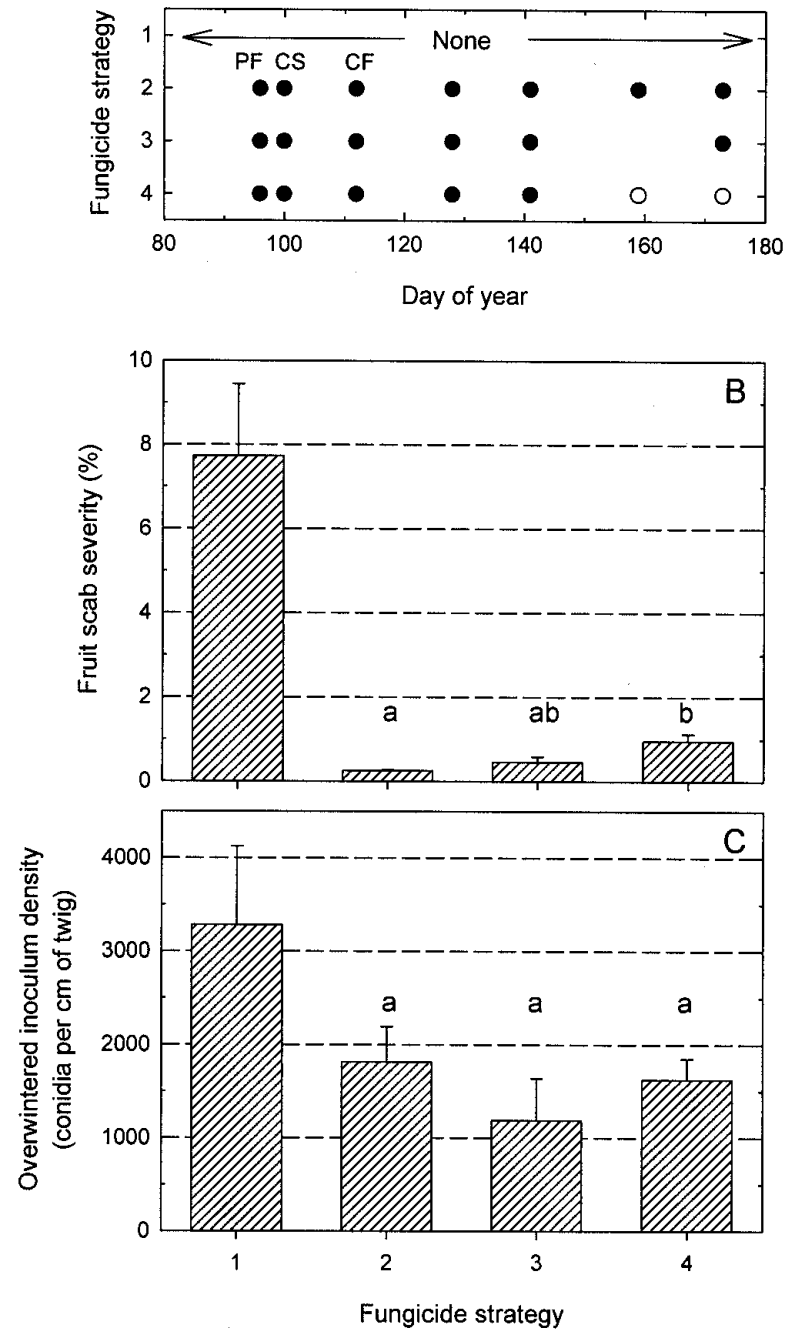

Fig. 4. Commercial peach orchard cv. Flameprince, 1998, site B: A, fungicide application timing; $\mathbf{B}$, fruit scab severity at harvest, and $\mathbf{C}$, density of overwintered inoculum early in the following year in a study of reduced fungicide programs against Cladosporium carpophilum. Solid and open symbols in $\mathbf{A}$ indicate conventional and alternate-row middle sprays, respectively. Values in $\mathbf{B}$ and $\mathbf{C}$ are means and standard errors of three replicate plots with 120 fruit or 10 twigs assessed per plot; means with the same letter are not significantly different according to a multiple $t$ test at $\alpha=0.05$, whereby data from untreated control plots were excluded from the analysis. $\mathrm{PF}=$ petal fall, $\mathrm{CS}=$ calyx split, $\mathrm{CF}=$ calyx fall. See Table 3 for fungicide schedules and rates. 
tially lower at site B, presumably because of a sulfur application made before sampling at petal fall.

\section{DISCUSSION}

This study showed that fungicide use in peach orchards in Georgia can be reduced without compromising scab control by using either extended-interval spraying or ARM spraying at reduced speed during midseason (after first or second cover), even in conditions of high disease pressure (on a late-season cultivar in an experimental orchard with many unsprayed trees). Reduced midseason fungicide programs also performed as well as the grower standard when evaluated in commercial conditions at site $\mathrm{A}$, but increased fruit scab was observed when used with a longer application interval at site B. Thus, although extended-interval and ARM spraying were limited to periods when scab pressure was thought to have decreased, the results emphasize the importance of maintaining sufficiently close application intervals. Sprays at site B likely were spaced too far apart (32 and 14 to 18 days for extendedinterval and ARM spraying, respectively) for satisfactory scab control without simultaneously increasing the sulfur concentration in the sprays, as was done in the experimental orchard. The need for sufficiently close application intervals with the ARM spray technique to maintain adequate levels of pesticide residue has been emphasized previously based on research in apple orchards $(6,15)$.

In the experimental orchard in both years, captan did not significantly improve scab control compared with sulfur when both compounds were applied via ARM spraying during midseason. While it is well established that captan is more effective than sulfur in a season-long spray program (24), the present study compared the two fungicides only during periods of reduced scab pressure after first cover, thereby negating the relative performance advantage of captan. It should be noted, however, that fruit in captan-treated plots generally showed improved coloring and finish compared with fruit in sulfur-treated plots (data not shown). This phenomenon has been reported previously after cover sprays with captan (15).

Sulfur residues measured on peach fruit in the experimental orchard were comparable in magnitude to those reported previously for cashew leaves after treatment with elemental sulfur to control powdery mildew (20). Residues in the present study were similar for trees sprayed via the ARM technique compared with those sprayed conventionally, indicating adequate penetration of the ARM spray into the canopy. The equivalent amount of residue was probably due to the fact that the same amount of active ingredient was applied per hectare in the ARM plots compared with the standard plots. In addition, sprayer speed was reduced by $25 \%$ in the ARM plots to further improve spray penetration and coverage. Despite slower sprayer speed, time savings with the ARM technique were $>25 \%$ compared with conventional spraying because the sprayer was operated only in every other row and because less refilling of the sprayer was needed. On a commercial scale, the time savings associated with ARM spraying should facilitate prompt response to weather-related increases in disease pressure and to reapplication after heavy rains.

Hogmire et al. (10) applied nigrosine dye to peach trees via airblast spraying and noted that spray deposit from adjacent rows contributed 18 to $39 \%$ to the total deposit measured in the periphery of peach trees. When the dye was applied at multiple times throughout the growing season to determine variations in coverage in relation to tree growth as the season progressed, coverage dropped rapidly between subsequent applications at the time of leaf expansion (within 6 weeks of full bloom), followed by a more modest drop between applications throughout the remainder of the season. Sulfur residue measurements in the present study were made after the second cover spray, after the greatest drop in coverage associated with leaf expansion $(9,10)$ was expected to have occurred. Further studies are needed to determine the dynamics of sulfur residues on peach fruit throughout the growing season in relation to application technique, spray interval, and environment, as well as the sulfur concentration needed to prevent infection by $C$. carpophilum in controlled conditions.

A potential concern with any reduced fungicide program is the possibility of inoculum buildup during subsequent growing seasons. It is conceivable that reduced midseason fungicide programs, while effective in controlling fruit scab, could allow increased twig infection, thereby leading to increased densities of primary inoculum the following year. This concern was not supported by the present study, in
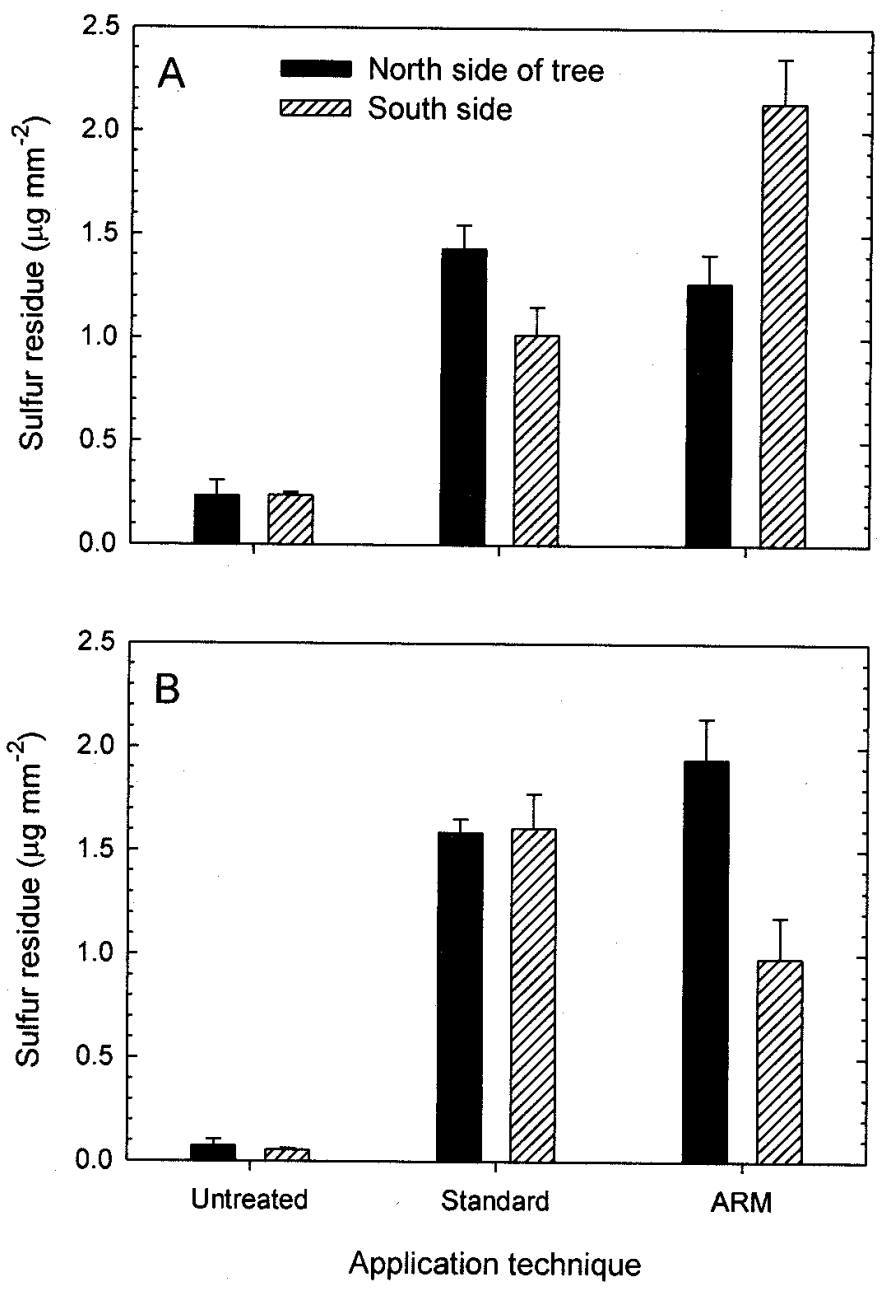

Fig. 5. Sulfur concentrations on fruit in a study of reduced fungicide programs against Cladosporium carpophilum in an experimental peach orchard cv. Blake. Concentrations were determined after the second cover spray on A, 7 May 1997, and B, 11 May 1998. See Table 1 for explanation of treatment strategies and fungicide rates. In the treatment receiving the alternate-row middle (ARM) application, the sprayer was operated in the row middle adjacent to $\mathbf{A}$, the south side, or $\mathbf{B}$, the north side of each sampled tree. Values are means and standard errors of four replicate plots with 10 fruit analyzed per plot. 
which reduced midseason fungicide programs did not lead to increased conidial counts on 1-year-old overwintered twigs at petal fall. Most infections on expanding, current-season twigs occurs at approximately the same time as fruit infections $(13,14)$, thus a fungicide program that controls fruit infection should also limit twig infection. Lawrence and Zehr (14) noticed that additional twig lesions appeared after harvest in September in an unsprayed orchard, but these may have been due to secondary infections originating from conidia produced on fruit lesions. In a well-managed orchard in the near absence of fruit scab, a second generation of twig lesions is less likely to occur.

Reduced fungicide programs have been investigated by several researchers since a season-long fungicide schedule was adopted for scab control in southeastern peaches in the early 1950s. Zehr et al. (24) noted that only four applications of captan were needed to achieve a level of scab control equal to that achieved with seven applications of sulfur. Captanbased fungicide programs have not been adopted for scab control by growers in Georgia, however, due to the higher cost of the material compared with sulfur. Chandler (3) reported that a benomylbased program including one application against scab at calyx split, followed by another application 2 weeks later, was as effective as a full-season sulfur program with five to seven sprays. Due to the development of benomyl resistance in populations of $C$. carpophilum in the southeastern United States (4), however, benomyl-based programs are not currently recommended for scab control. The potential for a peach fungicide program based on ARM spraying has also been investigated. In a 1-year study, Taylor and Couvillon (22) observed that a seasonlong ARM schedule with captan applied at weekly intervals resulted in scab control not significantly different from a schedule based on conventional applications every 2 weeks; however, seasonlong ARM spraying every 2 weeks resulted in greater levels of scab and brown rot. Their results differ from those observed in our study in which ARM spraying was limited to periods with reduced scab pressure. In addition, due to the high risk of brown rot epidemics in the southeastern United States, ARM spraying would be inadvisable for preharvest brown rot control.
Due to the recent regulatory scrutiny focused on organophosphate insecticides (7), the impetus for reduced pesticide programs in peach is driven primarily by the desire to use insecticides more judiciously. Insecticide use in southeastern peaches during midseason is targeted chiefly against the plum curculio (Conotrachelus nenuphar) (11). Integrated pest management programs are being developed to reduce insecticide input during this period, using either ARM spraying at regular intervals (12) or conventional sprays timed according to models of plum curculio development $(\mathrm{Z}$. Lan, H. Scherm, and D. L. Horton, unpublished). The latter program would reduce the number of insecticide sprays during midseason, thereby leading to longer intervals between applications. Because fungicides are generally tankmixed and applied simultaneously with insecticides, both programs would also impact disease control. Results of the present study suggest that commercially acceptable scab control is compatible with both ARM spraying and conventional applications at longer intervals during midseason. Further research is needed to evaluate insect and disease levels following combined ARM spraying of insecticide and fungicide and to determine whether fungicides in a tank mix timed for optimal plum curculio control during midseason will control scab effectively.

\section{ACKNOWLEDGMENTS}

Funded by the Georgia Peach Council and the Georgia Agricultural Commodity Commission for Peaches. We thank Big Six Farms and Dickey Farms for their cooperation.

\section{LITERATURE CITED}

1. Anonymous. 1995. United States Standards for Grades of Peaches. U.S. Department of Agriculture, Agricultural Marketing Service, Fruit and Vegetable Division, Fresh Products Branch, Washington, DC.

2. Bartlett, J. K., and Skoog, D. A. 1954. Colorimetric determination of elemental sulfur in hydrocarbons. Anal. Chem. 26:1008-1011.

3. Chandler, W. A. 1974. Control of peach disease with benomyl in full and modified schedules. HortScience 9:332-333.

4. Chandler, W. A., Daniell, J.W., and Littrell, R.H. 1978. Control of peach diseases in an orchard having benomyl-tolerant Cladosporium carpophilum. Plant Dis. Rep. 62:783786.

5. Cook, M. J., and Scherm, H. 1999. Antisporulant activity of early-season fungicide sprays against peach scab, 1998. F\&N Tests 54:53.

6. Hall, F. R. 1984. Evaluation of alternate row middle (ARM) spraying for apple orchards. Pages 17-21 in: Fruit Crops 1984: A Sum- mary of Research. Research Circular 283, Ohio State University, Wooster.

7. Hanson, D. 1999. EPA restricts use of organophosphates. Chemical \& Engineering News 77(32):5-6.

8. Hendrix, F. F., Jr. 1995. Scab. Pages 11-12 in: Compendium of Stone Fruit Diseases. J. M. Ogawa, E. I. Zehr, G. W. Bird, D. F. Ritchie, K. Uriu, and J. K. Uyemoto, eds. APS Press, St. Paul, MN

9. Hogmire, H. W., and Biggs, A. R. 1994. Reduced pesticide programme for peach based on tree phenology. Crop Prot. 13:277-280.

10. Hogmire, H. W., Wimmer, M. J., Crim, V. L., Welker, R. M., Wentz, E., and Smith, R. R. 1992. Influence of tree growth on spray chemical deposits on peach leaves. J. Agric. Sci. (Cambr.) 118:77-81.

11. Horton, D., Gorsuch, C., and Ritchie, D. (eds.) 2000. 2000 Southern Peach, Nectarine and Plum Pest Management and Culture Guide. Bulletin 1171, University of Georgia Cooperative Extension Service, Athens.

12. Horton, D. L., Hendrix, F. F., Chang, S., Yonce, C. E., and Payne, J. A. 1994. Alternate-row-middle insecticide application in southeastern peaches. ARS 122:147-148.

13. Keitt, G. W. 1917. Peach scab and its control. USDA Bull. 395:1-66.

14. Lawrence, E. G., Jr., and Zehr, E. I. 1982. Environmental effects on the development and dissemination of Cladosporium carpophilum on peach. Phytopathology 72:773-776.

15. Lewis, F. H., and Hickey, K. D. 1972. Fungicide usage on deciduous fruit trees. Annu. Rev. Phytopathol. 10:399-428.

16. Miller, R. W., and Bertrand, P. 1989. Peach scab. Pages 113-115 in: Peach Production Handbook. S. C. Myers, ed. Handbook No. 1, University of Georgia Cooperative Extension Service, Athens.

17. Petersen, D. H., and Dunegan, J. C. 1955 Factors influencing the control of peach scab in South Carolina. Plant Dis. Rep. 39:134140.

18. Savelle, A. T., and Scherm, H. 1998. Peach scab control with reduced fungicide programs. Phytopathology 88 (Suppl.):S79.

19. Scherm, H., and Savelle, A. T. 1998. Control of peach scab with reduced fungicide programmes. Ann. Appl. Biol. 132 (Suppl.):1819.

20. Smith, D. N., King, W. J., Topper, C. P. Boma, F., and Cooper, J. F. 1995. Alternative techniques for the application of sulphur dust to cashew trees for the control of powdery mildew caused by the fungus Oidium anacardii in Tanzania. Crop Prot. 14:555-560.

21. Sutton, T.B. 1996. Changing options for the control of deciduous fruit tree diseases. Annu. Rev. Phytopathol. 34:527-547.

22. Taylor, J., and Couvillon, G. A. 1975. The alternate row concept for spraying peaches. Ga. Agric. Res. 16(3):10-11.

23. Williams-Woodward, J. L. 2000. 1999 Georgia Plant Disease Loss Estimates. Path 99-02, University of Georgia Cooperative Extension Service, Athens.

24. Zehr, E. I., Miller, R. W., and Gorsuch, C. S. 1984. Reduced use of fungicides and insecticides on peaches. Pages 87-95 in: Proc. Joint Natl. Peach Council S.E. Peach Convention, Myrtle Beach, SC. 